\title{
Themes in International Psychiatry
}

\author{
David H. Skuse
}

Behavioural and Brain Sciences Unit, Institute of Child Health, London WC1 1EH, UK

\section{Editor}

Professor Hamid Ghodse

\section{Editorial board}

Dr JOHN HENDERSON

Mr DaVe Jago

Dr N ASSER LOZA

Dr Brian Martin dale

Professor Mary Robertson

Professor David Skuse

Design ๑ The Royal College of Psychiatrists 2003.

For copyright enquiries, please contact the Royal College of Psychiatrists.

All rights reserved. No part of this publication may be reprinted or reproduced or utilised in any form or by any electronic, mechanical or other means, now known or hereafter invented, including photocopying and recording, or in any information storage or retrieval system, without permission in writing from the publishers.

The views presented in this publication do not necessarily reflect those of the Royal College of Psychiatrists, and the publishers are not responsible for any error of omission or fact.

The Royal College of Psychiatrists is a registered charity (no. 228636).

Printed in the UK by Henry Ling Limited at the Dorset Press, Dorchester DT1 IHD. $\mathrm{n}$ this, the inaugural issue of International Psychiatry, we are highlighting the first of many themes that are of interest and concern to psychiatrists around the globe. Terrorism is both directly and indirectly the predominant topic in our media at present. What impact does living with such a threat, an 'everpresent danger', have on our mental health? Even if we are not directly affected by terrorism, psychiatrists cannot ignore the effects such incidents have had on societies in both the developed and the developing world.

We have commissioned a series of articles which report how different aspects of the terro rist threat have influenced the lives of people around the world. Four articles appear in this issue and a further set will follow in the second issue of International Psychiatry.

Herman and Susser discuss the effects of the events of 11 September 2001 on people living in Manhattan and make recommendations about how psychiatric services should respond in such circumstances. They emphasise the need for advance planning.

$\mathrm{N}$ jenga and colleagues discuss the traumatic events in $\mathrm{N}$ airobi, Kenya, in 1998, when a huge bomb destroyed the American embassy. M any Africans suffer severe trauma more frequently than citizens in the U nited States, but their psychiatric services are far less well equipped to deal with the sequelae of such events. It is arguably a responsibility of psychiatrists in the developed world to assist in mental health promotion within developing societies. We learn about the Mental H ealth Policy Support Project, which is co-sponsored by the WHO and the UK D epartment for International D evelopment; the hope is that the Kenyan model will be replicated in other countries.

De Jong, Komproe and Van 0 mmeren challenge psychiatrists to consider what is an appropriate professional role in response to terrorist-inspired events. In a controversial article, they argue that it is the responsibility (and indeed the nature) of a culture to respond with a netw ork of supportive structures and rituals. This is exactly what happened in Kenya - a recourse to prayer and support from the family. We need to consider, though, whether this is enough. $N$ jenga and colleagues think not. $O n$ the other hand, are we, in the Western world, in danger of going to $\mathrm{far}$ in the direction of 'pathologising' experience, to the extent that professional support will be sought after exposure to traumas that are a lot less dramatic than 11 September? And if so, does it matter?

Finally, in a thought-provoking reflection on events in $\mathrm{N}$ orthern Ireland, Lord Alderdice discusses the way in which a so ciety that has lived with 'Troubles' for many years adjusted to chronic threat. D espite the persistent danger, there is no evidence that this translated into heightened vulnerability to mental ill-health.

0 ur readers will understand that the views of the authors expressed in these articles are not the views of the Royal College; nor are they necessarily the views of the editors of this novel bulletin. Enjoy and reflect. We hope you will appreciate them as much as we did.

\section{The World Trade Center attack: mental health needs and treatment implications}

\author{
Daniel B. Herman ${ }^{1}$ and Ezra S. Susser ${ }^{2}$
}

${ }^{1}$ Assistant Professor of Clinical Epidemiology, Joseph L. Mailman School of Public Health, Columbia University, and Research Scientist, Epidemiology of Mental Disorders Research Department, New York State Psychiatric Institute

2Professor of Epidemiology and Psychiatry, Columbia University College of Physicians and Surgeons, Head of Department of Epidemiology, Joseph L. Mailman School of Public Health, Columbia University, and Department Head, Epidemiology of Brain Disorders, New York State Psychiatric Institute

n 11 September 2001, the United States suffered the worst terrorist attacks in its history. In N ew York City, approximately 3000 persons were killed at the World Trade Center, while many thousands fled for their lives. Millions of other city residents observed the burning towers and breathed the acrid smoke that blanketed the city. Compounding the massive physical destruction and loss of life, the psychological impact of these terrifying events on the populace was profound there were significant increases in mental distress and symptoms of disorder. 
aftermath of the attacks of 11 September, such factors associated with the development of PTSD include job loss, female sex, low social support and more life stressors experienced in the preceding 12 months (Schlenger et al, 2002; G alea et al, 2002b).

\section{Time course}

The ultimate course of these disorders remains to be seen. Regarding PTSD per se, short-term follow-up data suggest that the majority of cases may have resolved fairly rapidly; the reported rate of current PTSD related to 11 September in Manhattan had declined to $1.7 \%$ by January 2002, and rates of depression had also decreased significantly ( $G$ alea et al, 2002c). These declining rates are consistent with some but not all previous studies of PTSD (Kessler et al, 1995; N orth et al, 1999). N one the less, the absolute number of persons experiencing ongoing PTSD resulting from the attacks several months afterwards still exceeded 100 000, while there may still be delayed-onset cases that have yet to manifest.

\section{Service provision}

Thus, the attacks of 11 September had a profound effect on the mental health of $\mathrm{N}$ ew Yorkers. What are the implications of these findings for psychiatrists and other mental health providers who may be called upon to respond to community needs following a major terror attack? In the aftermath of such an event, the requisite mental health service response can be expected to unfold in acute and post-acute phases. The duration of these phases is dictated by the intensity of the disaster, the degree of ongoing threat and the response of the community.

\section{Acute phase}

Services needed during the acute phase include crisis intervention, psycho-education, and social support to help people cope with psychological distress caused by exposure to the disaster. Much of this w ork is delivered 'in vivo' - in schools, places of worship, and other emergency recovery settings, rather than formal mental health settings. In general, communities (including $\mathrm{N}$ ew York) have been inadequately prepared to mobilise resources in the immediate wake of mass disaster, and this has greatly limited their capacity to deliver interventions effectively. Although it is hoped that these early intervention efforts, in addition to their immediate palliative effects, will also confer ongoing benefits, there is scant empirical evidence of their long-term impact ( $\mathrm{N}$ ational Institute of Mental H ealth, 2002). In particular, a recent review of studies of psychological 'debriefing' (the most commonly studied model) concluded that it is ineffective in reducing the risk of subsequent PTSD and other disorders (Suzanna et al, 2001).

\section{Post-acute phase}

After the acute phase, the focus largely shifts to the treatment of diagnosable mental disorders, to persons whose symptoms have not resolved and to those who have
Since the World

Trade Center attack received an

unprecedented degree of

exceptionally

graphic media coverage, including live television broadcasts of the airplanes' impact, victims falling to their deaths and people fleeing for

their lives, some

have wondered

whether indirect exposure may also have increased the risk of subsequent disorder among viewers. 
experienced delayed onset of such disorders. Fortunately, there is a somewhat more well established research literature regarding effective treatments for mental disorders most likely to result from exposure to mass violence and severe trauma ( $\mathrm{N}$ ational Institute of Mental $\mathrm{H}$ ealth, 2002). A number of studies support the efficacy of cognitivebehavioural psychotherapeutic interventions for PTSD, while there is also some empirical support for group and individual psychodynamic therapy. Pharmacotherapy may also provide benefit for people experiencing PTSD, as dysregulation of numerous psychobio logical systems is often associated with it. In addition, the high frequency of co-occurring psychiatric disorders among people with PTSD underscores the importance of considering pharmacotherapy in the treatment of PTSD (Foa \& International Society for Traumatic Stress Studies, 2000).

\section{Community response}

Although the treatments described above are focused on individuals, families and small groups, the need to target interventions at the broader community level should not be overlooked. Activities that focus on bringing to gether members of the community to provide social and emotional support for persons who have suffered significant losses enhance social cohesion and mutual support, which, in turn, have important health and mental health benefits. As exemplified by $\mathrm{N}$ ew York Mayor Rudolph Giuliani's leadership in the days following 11 September, community resilience is also greatly enhanced by government leaders who can effectively promote a sense of common purpose and optimism even in the face of enormous tragedy.

Finally, it is essential to have an infrastructure in place beforehand if effective mental health interventions are to be delivered following large-scale terrorist events. This includes comprehensive planning for a coordinated response, a well-trained workforce, and greater recognition on the part of government authorities that attending to mental health concerns is a crucial component of public health preparedness in a time of terror.

\section{References}

Foa, E. B. \& International Society for Traumatic Stress Studies (2000) Effective Treatments for PTSD: Practice Guidelines from the International Society for Traumatic Stress Studies. N ew York: Guilford Press.

Galea, S., Ahern, J., Resnick, H., et al (2002a) Psychological sequelae of the September 11 terrorist attacks in $\mathrm{N}$ ew York City. N ew England Journal of Medicine, 346, 982-987.

Galea, S., Resnick, H., Ahern, J., et al (2002b) Posttraumatic stress disorder in Manhattan, $\mathrm{N}$ ew York City, after the September 11th terrorist attacks. Journal of Urban H ealth, 79, 340-353.

Galea, S., Boscarino, J., Resnick, H., et al (2002c) Mental health in $\mathrm{N}$ ew York City after the September 11 terrorist attacks: results from two population surveys. In Mental $\mathrm{H}$ ealth, United States, 2001 (ed. M. H. R. W. Manderscheid). Washington, DC: US Government Printing $O$ ffice.

Herman, D., Felton, C. \& Susser, E. (2002) Mental health needs in $\mathrm{N}$ ew York State following the September 11th attacks. Journal of Urban Health, 79, 322-331.

Hoven, C. W., Duarte, C., Lucas, C., et al (2002) Effects of the World Trade Center Attack on NYC Public School Students Initial Report to the N ew York City Board of Education. N ew York: Columbia University Mailman School of Public Health, $\mathrm{N} \mathrm{ew}$ York State Psychiatric Institute and Applied Research and Consulting, LLC.

Kessler, R. C. Sonnega, A., Bromet, E. et al (1995) Posttraumatic stress disorder in the $\mathrm{N}$ ational Comorbidity Survey. Archives of General Psychiatry, 52, 1048-1060.

$\mathrm{N}$ ational Institute of Mental $\mathrm{H}$ ealth (2002) M ental Health and M ass Violence: Evidence-Based Early Psychological Intervention for Victims/Survivors of Mass Violence. A Workshop to Reach Consensus on Best Practices. N IH Publication N 0. 02-5138. Washington, DC: US Government Printing 0 ffice.

Norris, F. H. (2001) 50,000 Disaster Victims Speak: An Empirical Review of the Empirical Literature, 1981-2001. National Center for PTSD, Center for Mental Health Services (SAMSHA).

North, C. S., Nixon, S. J., Shariat, S., et al (1999) Psychiatric disorders among survivors of the 0 klahoma City bombing. Journal of the American Medical Association, 282, 755-762.

Schlenger, W. E., Caddell, J. M., Ebert, L., et al (2002) Psychological reactions to terrorist attacks: findings from the $\mathrm{N}$ ational Study of Americans' Reactions to September 11. Journal of the American Medical Association, 288, 581-588.

Schuster, M., Stein, B., Jaycox, L., et al (2001) A national survey of stress reactions after the September 11, 2001, terrorist attacks. N ew England Journal of Medicine, 345, 1507-1512.

Sprang, G. (1999) Post-disaster stress following the 0 klahoma City bombing: an examination of three community groups. Journal of Interpersonal Violence, 14, 169-183.

Susser, E. S., Herman, D. B. \& Aaron, B. (2002) Combating the terror of terrorism. Scientific American, 287(2), 70-77.

Suzanna, R., Jonathan, B. \& Simon, W. (2001) Psychological debriefing for preventing post traumatic stress disorder (PTSD). Cochrane Database of Systematic Reviews, 3, CD 000560.

\title{
Africa: the traumatised continent, a continent with hope
}

\author{
F. G. Njenga, P. Kigamwa and M. Okonji
}

Kenya Psychiatric Association, PO Box 73749, Nairobi, Kenya, email fnjenga@africaonline.co.ke

\begin{abstract}
$M$ any African countries gained political independence in the 1960s and 1970s and went through difficult times in economic, political and security terms in the 1980 s and early 1990s. Mental health services and research were not spared and stagnated or deteriorated during this period. The effects of poor governance, inequit-
\end{abstract}

able distribution of resources and environmental degradation conspired with natural and man-made disasters (wars in particular) to drive Africa into an abyss of despair.

In East, West, Central and Southern Africa, there is presently fighting over issues that seem unclear even to the combatants. Conflicts, including wars and civil strife, 